catalogue may be mentioned a thirteenth century medical manuscript on vellum containing some of the works of Constantinus Africanus, Giles of Corbeil and others, the work of Bartholomaeus Anglicus entitled "Do Proprietatibus Rerum" (1535), Ambroise Paré's "Dix Livres do la Chirurgie" (1564), Gasparo Aselli's book on the lacteals (1627), Robert Boyle's "Sceptical Chymist" (1661) and modern works by Oliver Wendell Holmes, Sir William Osler and s. Weir Mitchell.

\section{The Science Library}

THE Science Library, Science Museum, South Kensington, is remaining open. Books and periodicals are available for consultation in the reading room and for external loan to institutions engaged on research work. A relatively small number of the older books and periodicals have been removed and aro not at present available. Although difficulty is anticipated, every endeavour will be mado to maintain the collection of important current foreign scientific and technical literature up to the pre-war degree of completeness. The bibliographical and information service of the I,ibrary will be maintained so far as the reduced resources permit.

\section{Royal Astronomical Society}

THE meetings of the Royal Astronomical Society will continue to be held at Burlington House, Lon. don, but at an earlier hour. The Monthly Notices and also Occasional Notes will be published so far as possible, but the former will not necessarily appear each month. The library will be closed except on meeting days, as the assistant secretary and office have been transferred to Oxford. Tho Christmas lecture, soirées, etc., have been postponed indefinitely. Prof. H. H. Plaskett, the senior secretary, is serving in the Roynl Artillery, and Prof. WV. M. H. Greaves has been appointed acting secretary for the present.

\section{British Astronomical Association}

THE annual general meeting of the British Astronomical Association will bo held as usual on October 25, in accordance with the articles of tho Association, and no arrangement has been made at present to alter procedure in the matter of ordinary meetings. The president, two secretaries and treasurer have been empowered to conduct the business of the Association if war-time emergency should cause a discontinuance of the meetings. If this contingency arises, the Journal will still be published monthly, and it is hoped that papers will be contributed as usual by members. The library will bo open only on tho second and fourth Wednesdays of each month, but the librarian has power to refrain from opening in case of emergency.

\section{Institute of Physics}

THE offices of the Institute of Physics have been transferred to the University of Reading, where accommodation had been reserved for them, by the kindness of the Council of the University. It is hoped to carry on so far as possible the normal work of the Institute, with such further activities as may be necessitated by emergency conditions. The Institute is in touch with Government departments and other employers, and has been collecting and collating such information as is available regarding the employment of physicists during war conditions. A considerable number of inquiries for advice on this and other emergency matters have received attention. It has been decided, unless unpredictable circumstances interveno, to continue the publication and distribution of the Journal of Scientific Instruments on the same terms as in the past, though it may be necessary to reduce to some extent the number of pages in each issue.

\section{Announcements}

Dr. Ian Galloway has been appointed scientific superintendent of research at the Pirbright Research Station of the Foot-and-Mouth Disease Research Committee.

DR. S. C. Harland has been appointed director of the Institute of Cotton Technology of the National Agricultural Society of Peru.

Str Frederick Menzies has resigned his position as medical officer of health and school medical officer of the London County Council, and has been succeeded by Dr. William Allen Daley.

IN the hopo of giving assistance to students in London who have been unable to follow their university colleges into the provinces in the present emergency, the managers of the Royal Institution have arranged for additional short courses of lectures to be given dealing in an introductory manner with certain subjects of modern physics and chemistry. Applications should be made to the Royal Institution, 21 Albemarle Streot, London, W.1.

IT is hoped to arrange day and/or evening courses in electrical methods of chemical analysis, microchemical analysis, spectroscopy and bacteriology at the Sir John Cass Technical Institute. Those wishing to take classes in these subjects should write, stating possible days and hours of attendance, to Dr. E. de Barry Barnett, Sir John Cass Technical Institute, Jewry Street, London, E.C.3.

Tre governing body of the British Medical Postgraduate School has decided to carry on postgraduate instruction for the present.

Owivg to the war, the International Iseague against Rheumatism will no longer bo able to carry out its activities, and its bureau at Keizergracht 489 , Amsterdam, will be closed.

Eighteen cases of smallpox were notified in England in 1938, of which nine were variola major and nine variola minor, and there were three deaths. These are the first deaths from smallpox which have occurred in England since 1934. 